\title{
INDICATIVE ECOLOGICAL STATUS ASSESSMENT OF THE DESPOTOVICA RIVER
}

\author{
Snežana B. Simić ${ }^{1 *}$, Ana S. Petrović ${ }^{1}$, Nevena B. Đorđevićc ${ }^{1}$ Božica M. Vasiljević ${ }^{2}$, \\ Nataša M. Radojković ${ }^{1}$, Aleksandra B. Mitrović ${ }^{1}$, Milutin G. Janković ${ }^{1}$ \\ ${ }^{1}$ University of Kragujevac, Faculty of Science, Institute of Biology and Ecology, \\ Radoja Domanovića 12, 34000 Kragujevac, Republic of Serbia \\ ${ }^{2}$ University of Belgrade, Institute for Biological Research "Siniša Stanković", \\ Despota Stefana 142, 11000 Beograd, Republic of Serbia \\ *Corresponding author; E-mail: snezasi@kg.ac.rs
}

(Received April 10, 2018; Accepted May 22, 2018)

\begin{abstract}
The investigation of the Despotovica River was carried out in April 2017 with the aim to provide an indicative ecological status assessment. Phytobenthos and aquatic macroinvertebrate communities were followed as well as physico-chemical parameters of water. Ecological status assessment is given based on biological (epilithic diatoms and macroinvertebrates) and supporting physico-chemical water quality elements, according to the Serbian National regulation on parameters of ecological and chemical status of surface waters and parameters of chemical and quantitative status of ground waters. The ecological status was determined by the worst evaluated water quality element. Based on the analysis of investigated parameters of biological and physico-chemical water quality elements, the indicative ecological status of the Despotovica River could be assessed as bad (class V), which is the result of the river's load of organic and inorganic origin but also of heavy metals.
\end{abstract}

Keywords: ecological status, Despotovica River, epilithic diatoms, macroinvertebrates.

\section{INTRODUCTION}

The investigation in the field of the traditionally used term "water quality", contributed to the establishment of a new approach to water monitoring, in which the ecological status of the aquatic ecosystem as an expression of the quality of the structure and functioning, specific for each type of water body (WFD, 2000). The Water Framework Directive regulates the management of aquatic ecosystems in the territory of the European Union and provides a new approach to water monitoring. According to the principles of the WFD (WFD, 2000), the status of surface waters assesses on the base of ecological and chemical status, whereby it has been determined by worse than ecological and chemical status (DENIĆ et al., 2015a).

According to the WFD (WFD, 2000) systemic monitoring is necessary, which includes all relevant parameters of biological quality elements, as well as parameters of supporting chemical, physico-chemical and hydromorphological quality elements. Ecological 
status assessment determines the worst evaluated biological quality element, while the condition of physico-chemical and hydromorphological quality elements has an indirect affect to assessment through their influence on the condition of biological quality elements and had to be aligned with evaluation of biological quality elements (DENIĆ et al., 2015a).

The implementation of the WFD (2000) in Serbia began with adopting the Water Law (ANONYMOUS, 2010a) and by-laws harmonized with them. Adopting the Serbian National regulative (ANONYMOUS, 2010b, 2011a; 2011b, 2012) ecological status assessment based on biological (phytoplankton, phytobenthos, macrophytes and fish) and chemical, physicochemical and hydromorphological quality elements, of relevance to biological quality elements, was established.

Monitoring of surface waters, according to WFD (WFD, 2000), and in accordance with the legislation and by-laws in this field, has been implemented in Serbia since 2012. For ecological status/potential assessment of a large number of water bodies from biological quality elements were used algae (phytoplankton and benthic diatoms) (KRIZMANIĆ et al., 2013, 2015; VIDAKOVIĆ, 2013; DENIĆ et al., 2014a, 2014b, 2015b, 2015c; JAKOVLJEVIĆ et al., 2014; 2016a, 2016b; PredoJEVIĆ, 2017; VASILJEVIĆ et al., 2014, 2016, 2017; VASILJEVIĆ, 2017), macroinvertebrates, (MARKOVIĆ et al., 2011; NOVAKOVIĆ, 2012, 2013a, 2013b, 2014; ILIĆ et al., 2013; POPOVIĆ et al., 2015a, 2015b; ŽUNIĆ et al., 2015; ZoRIĆ et al., 2016), or rarely phytoplankton, benthic diatoms and macroinvertebrates at the same time (DENIĆ et al., 2014a, 2015b; ČAĐO et al., 2016, 2017; STOJANOVIĆ et al., 2017).

The aim of this study was to assess the ecological status of the Despotovica River based on biological (epilithic diatoms and aquatic macroinvertebrates) and supporting physico-chemical water quality elements, recommended by National regulation (ANONYMOUS, 2011b).

\section{MATERIALS AND METHODS}

\section{Study area}

The Despotovica River is located in central Serbia (Figure 1a). It springs in southern slopes of the Rudnik Mountain, under the name Rudnik River. It connects with the Majdan River in Majdan village and builds the Despotovica River. The Despotovica River runs between Vujan and Ilijak, creating a gorge between Gornji Milanovac and Brđani. In the village of Brđani, after leaving the gorge, the Despotovica River flows into the Dičina River, which through the Čemernica River flows away to the Zapadna Morava River. The area of the Despotovica basin is $220 \mathrm{~km}^{2}$, the length of the stream is $24 \mathrm{~km}$, and the average flow rate at the mouth is $0.5 \mathrm{~m}^{3} / \mathrm{s}$. It belongs to the Black Sea Basin (DRINJAKOVIĆ et al., 2015).

Considering the waste water entry from the flotation of the lead, copper and zinc mine in the Rudnik mountain, as well as the technological and communal waste water of Gornji Milanovac town, the Despotovica River belongs to the group of polluted rivers of Serbia (GAVRILOVIĆ AND DuKIĆ, 2002; DrinJAKOVIĆ et al., 2015; SimiĆ et al., 2015).

\section{Collecting samples and accompanying location data}

Investigation of the Despotovica River was performed in April 2017 at five sampling sites (L1 - above the tailings pond; L2 - under the tailings pond; L3 - above the "Foka" factory; L4 - Mlakovac; and L5 - Brđani under the landfill) (Figure 1b). Biological (phytobenthos and macroinvertebrates) and supporting physico-chemical water quality elements were followed. 


\section{Phytobenthos}

At all five localities of the Despotovica River, from phytobenthos community, macroalgae thalli and epilithic diatoms were collected. Sampling of epilithic diatoms was performed according to following standard (EN 19346, 2015). All collected samples were immediately preserved in $4 \%$ formaldechyde. Macroalgae were observed on temporary preparations. For treatment of the epilithic diatom samples standard method with concentrated sulfiric acid was used (KRAMMER and LANGE-BERTALOT, 1986). Microscopic examination of the permanent slides was done using the light microscope Motic B310 with digital camera BRESSER (9MP) and MicroCamLab software. Identification of the present taxa was done using the appropriate literature (KRAMMER and LANGE-BERTALOT, 1986, 1988, 1991; WEHR and SHEATH, 2003; KomÁREK and ANAGNOSTIDIS, 2005). Besides to above literature, on-line identification keys were used as additional resources (SPAULDING et al., 2010; KocIOLEK, 2012). Qualitative and quantitative analysis of epilithic diatoms was performed according to following standard (EN 14407, 2015). Quantitative analysis was based on the relative abundance of identified taxa, represented by valve percentage of each taxon relative to 400 counted valves on each permanent slide.

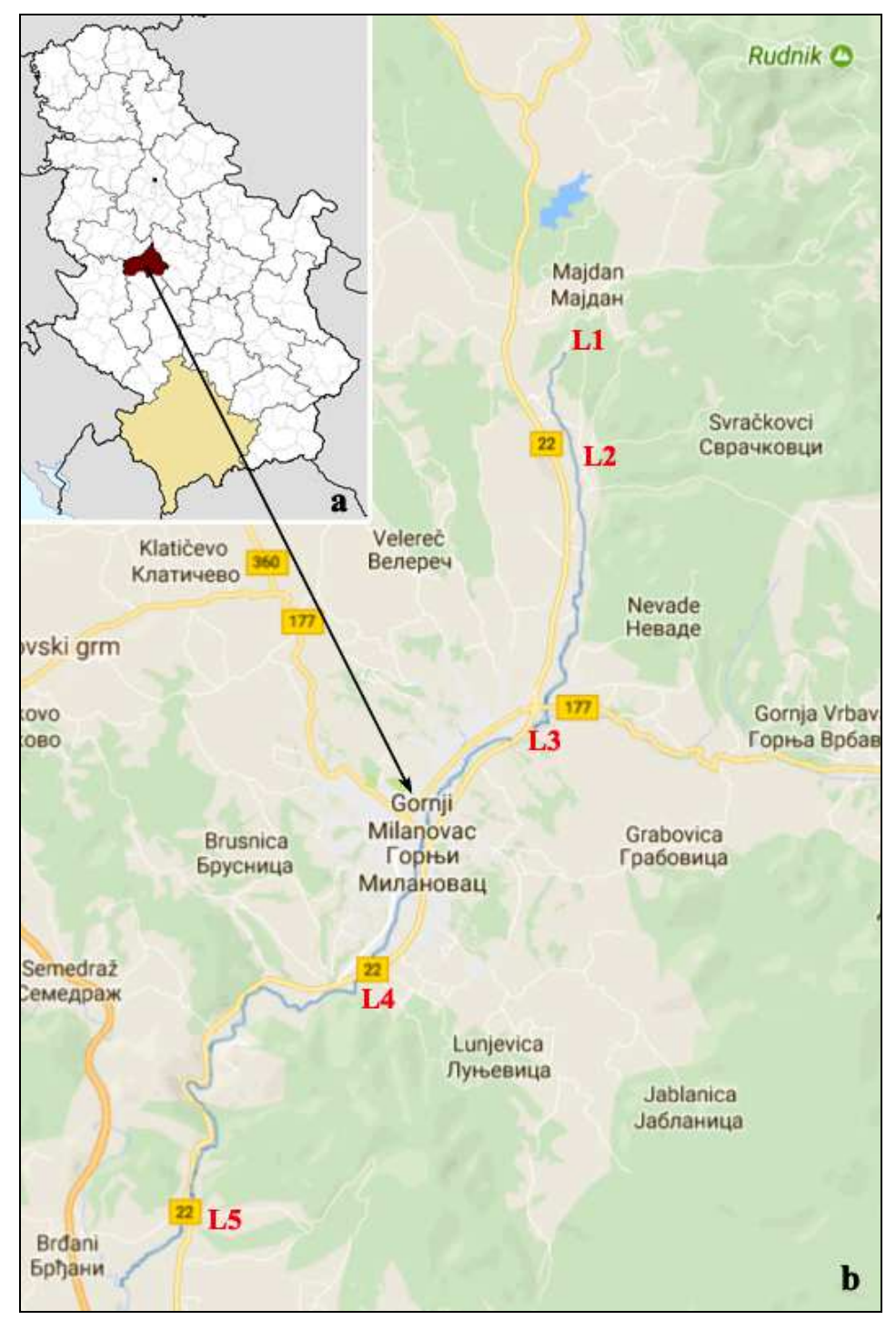

Figure 1. a) Position of the Despotovica River in Serbia; b) Sampling sites of the Despotovica River. 
Based on qualitative and quantitative analysis of epilithic diatoms we calculated diatom indices using OMNIDIA software (LECOINTE et al., 1993).

\section{Aquatic macroinvertebrates}

Aquatic macroinvertebrate samples were collected according to AQEM protocol. Benthic samples were taken with a $0.0625 \mathrm{~m}^{2}$ Surber sampler of $250-\mu \mathrm{m}$ mesh. Samples were preserved using $70 \%$ ethanol solution and analysed in laboratory. The study included qualitative and quantitative analysis of the benthic community. Qualitative analysis was done using a binocular microscope (NIKON SMZ800) and identification keys (BELFIORE, 1983; HRABINOVÁ and BITUŠÍK, 2003; MAGAN, 1955; MANN and WATSON, 1964; ROYKOŠNÝ, 1980). Quantitative analysis was carried out by the absolute counting of individuals of each present species.

\section{Physico-chemical properties of water}

Water samples were taken from all localities, according to following standard (EN ISO 5667, 2017). We followed water temperature $\left({ }^{\circ} \mathrm{C}\right)$, conductivity $\left(\mu \mathrm{S} / \mathrm{cm}^{3}\right)$, water hardness $(\mathrm{mg} / \mathrm{l}), \mathrm{pH}$, dissolved oxygen $(\mathrm{mg} / \mathrm{l})$, oxygen saturation $(\%)$, ammonium ion $(\mathrm{mg} / \mathrm{l})$, nitrates $(\mathrm{mg} / \mathrm{l})$, orthophosphates $(\mathrm{mg} / \mathrm{l})$, total phosphorus $(\mathrm{mg} / \mathrm{l})$. Physico-chemical parameters of water were measured by a set of field laboratory mark "AQUALITIC AL450".

\section{Ecological status assessment}

Ecological status assessment of the Despotovica River is based on a threshold value of status classes for biological (epilithic diatoms and macroinvertebrates) and physico-chemical water quality elements, according to Serbian national regulation on parameters of ecological and chemical status of surface waters and parameters of chemical and quantitative status of ground waters (ANONYMOUS, 2011b). An assessment of ecological status was given based on the worst evaluated parameter of biological and supporting physico-chemical water quality elements.

For ecological status assessment on benthic diatoms National regulative defines a threshold values for two diatom indices: IPS - "Indice de pollution-sensibilite" (CEMAGREF, 1982) and CEE - "Comission for Economical Community metric" (DESCY AND COSTE, 1991).

The parameters of macroinvertebrate community, used to evaluate the ecological status, were: Zelinka and Marvan Saprobic Index (ZELINKA and MARVAN, 1961), Biological Monitoring Working Party (BMWP) Score (CHESTER, 1980), ASPT-Average Score per Taxon (ARmitage et al, 1983), ShannonWeaver's Diversity Index (Shannon, 1948), percentage participation of Oligochaeta/Tubificidae in the total macroinvertebrate community, number of Ephemeroptera, Plecoptera and Trichoptera (EPT) taxa and total number of families (AQEM, 2002). Based on the community of macroinvertebrate used for indicative ecological status assessment, Balkan Biotic Index (BNBI) was used (SIMIĆ and SIMIĆ, 1999) according to the national legislation (ANONYMOUS, 2011b).

For saprobiological analysis, a list of bioindicator organisms according to Moog was applied (Moog, 1995). Due to a complex identification process, as well as low level of confidence, certain taxa were not identified to the species level. The metrics calculation was performed using ASTERICS software (AQEM, 2002), and the indicative ecological status assessment was performed in accordance with the national legislation (ANONYMOUS, 2011b), based on the class boundaries for rivers Type 3 (small and medium watercourses, altitude up to $500 \mathrm{~m}$ ), as presented in Table 5 . 
Parameters on supporting physico-chemical quality elements, used for ecological status assessment, were: dissolved oxygen $(\mathrm{mg} / \mathrm{l})$, ammonium-ion $(\mathrm{mg} / \mathrm{l})$, nitrate $(\mathrm{mg} / \mathrm{l})$, orthophosphate $(\mathrm{mg} / \mathrm{l})$ and total phosphorus $(\mathrm{mg} / \mathrm{l})$.

\section{RESULTS AND DISCUSSION}

\section{Phytobenthos community analysis}

In the examination of the phytobenthic samples, a total of 25 taxa were identified from four divisions: Cyanobacteria -3 , Xanthophyta -1 , Bacillariophyta -17 and Chlorophyta 4. The largest species diversity was recorded at L4 (18 taxa), while the smallest was recorded at L2 sampling site (4 taxa). At four sampling sites of the Despotovica River, macroalgae thalli was recorded: Cladophora glomerata (Linnaeus) Kützing (L1), Stigeoclonium tenue (C. Agardh) Kützing (L3, L4 i L5), Ulothrix zonata (F. Weber and Mohr) Kützing (L3 i L4) and Tribonema sp. Pascher (L4 i L5).

Table 1. Qualitative and quantitative analysis (percentages number of valves) of epilithic diatoms from the Despotovica River in April 2017.

\begin{tabular}{|c|c|c|c|c|c|}
\hline Localities & $\mathbf{L 1}$ & $\mathbf{L 2}$ & $\mathbf{L 3}$ & $\mathbf{L 4}$ & L5 \\
\hline Bacillariophyta taxa & \multicolumn{5}{|c|}{$\%$ number of valves } \\
\hline Achnanthidium microcephalum Kützing & 14.5 & 85.57 & 7.66 & & \\
\hline Amphora veneta Kützing & & 2.56 & 2.55 & & \\
\hline Cocconeis placentula Ehrenberg & 21.7 & & 5.43 & & 1.32 \\
\hline Diatoma vulgaris Bory & & & 0.95 & 1.99 & 1.6 \\
\hline Diatoma moniliformis D. M. Williams & & & & 1.32 & \\
\hline Eolimna minima Lange-Bertalot & 5.79 & & 10.22 & 3.32 & 3.32 \\
\hline Encyonema ventricosum Grunow & & & 22.68 & 11.2 & 6.64 \\
\hline Encyonopsis microcephala Krammer & & & & 6.64 & 7.64 \\
\hline Fragilaria ulna var. contracta Main & 7.24 & & 6.07 & 10.96 & 11.62 \\
\hline Gomphonema olivaceum Brébisson & 7.26 & 7.69 & & 11.95 & 6.64 \\
\hline Gomphonema parvulum Kützing & 28.98 & & 11.5 & 3.32 & 5.64 \\
\hline Navicula capitatoradiata $\mathrm{H}$. Germain & & & & 6.64 & 10.63 \\
\hline Navicula lanceolata Ehrenberg & & & 8.62 & 6.64 & 10.62 \\
\hline Nitzschia palea $\mathrm{W}$. Smith & & 3.2 & 5.76 & 14.95 & 8.97 \\
\hline Planothidium lanceolatum Ehrenberg & & & 11.18 & & \\
\hline Surirella brebissoni Krammer \& Lange-Bertalot & & & 4.47 & 17.6 & 12.62 \\
\hline Surirella minuta Brébisson ex Kützing & & & 2.87 & 3.32 & 3.98 \\
\hline Total number of taxa & 6 & 4 & 13 & 13 & 13 \\
\hline
\end{tabular}

From the total number of benthic diatoms, the largest number (13 taxa) was recorded at L3, L4 and L5, while the smallest was at L2 sampling site (4 taxa). The taxa detected in $80 \%$ of samples were Eolimna minima Lange-Bertalot, Fragilaria ulna var. contracta Main, Gomphonema olivaceum Brébisson, G. parvulum Kützing, and Nitzschia palea W. Smith (Table 1). The most dominant species was Achnanthidium microcephalum Kützing at L2 sampling site. The also very dominant species were Encyonema ventricosum Grunow (L3 sampling site) and G. parvulum (L1 sampling site). 
At L2, L3 and L4 sampling sites presence of teratological forms of A. microcephalum, $F$. ulna var. contracta and $N$. palea were recorded.

\section{Analysis of aquatic macroinvertebrate community}

In aquatic macroinvertebrate community a total of 23 taxa were identified, classified in eight groups: Coleoptera - 2, Crustacea-Amphipoda - 1, Diptera - 4, Ephemeroptera - 7, Hirudinea - 1, Oligochaeta - 1, Plecoptera - 2 i Trichoptera - 5 (Table 2).

The largest number of identified taxa belongs to the Ephemeroptera group, while the smallest number was recorded in Crustacea-Amphipoda, Hirudinea and Oligochaeta groups. Of the total 25 taxa, the largest number was recorded at L1 (12 taxa), while the smallest number ( 2 taxa) was recorded at L2. The most dominant taxon, in relation to the number, was Limnodrilus sp., while Chironomus sp. was present in $80 \%$ of the samples.

Table 2. Qualitative and quantitative analysis (absolute number of individuals) of macroinvertebrates from the Despotovica River in April 2017.

\begin{tabular}{|c|c|c|c|c|c|}
\hline Localities & $\mathbf{L 1}$ & $\mathbf{L 2}$ & L3 & L4 & L5 \\
\hline Macroinvertebrates taxa & \multicolumn{5}{|c|}{ Absolute number of individuals } \\
\hline \multicolumn{6}{|l|}{ Coleoptera } \\
\hline Hydraena gracilis Germar, 1824 & & & 1 & & \\
\hline Limnius sp. & & & 1 & 2 & \\
\hline \multicolumn{6}{|l|}{ Crustacea - Amphioda } \\
\hline Gammarus balcanicus Schäferna, 1922 & 9 & & & & \\
\hline \multicolumn{6}{|l|}{ Diptera } \\
\hline Chironomus sp. & 4 & & 7 & 39 & 35 \\
\hline Hexatoma sp. & 1 & & & & \\
\hline Tipula sp. & & & 1 & & \\
\hline Tabanus sp. & & & 1 & 1 & \\
\hline \multicolumn{6}{|l|}{ Ephemeroptera } \\
\hline Baetis sp. & 1 & & & & \\
\hline Baetis rhodani Pictet, 1843 & 23 & & & & \\
\hline Caenis horaria Linnaeus, 1758 & & & 8 & & \\
\hline Ecdyonurus sp. & & 1 & & & \\
\hline Ecdyonurus venosus Fabricius, 1775 & 10 & & & & \\
\hline Ephemerella sp. & & 1 & & & \\
\hline Rhithrogena sp. & 3 & & & & \\
\hline \multicolumn{6}{|l|}{ Hirudinea } \\
\hline Glossiphonia complanata Linnaeus, 1758 & & & & 4 & 6 \\
\hline \multicolumn{6}{|l|}{ Oligochaeta } \\
\hline Limnodrilus sp. g & & & & 148 & 3 \\
\hline \multicolumn{6}{|l|}{ Plecoptera } \\
\hline Brachyptera sp. & 4 & & & & \\
\hline Leuctra sp. & 5 & & & & \\
\hline \multicolumn{6}{|l|}{ Trichoptera } \\
\hline Agapetus sp. & 15 & & 1 & & \\
\hline Hydropsyche sp. & & & 1 & 1 & \\
\hline Limnephylus sp. & 1 & & & & \\
\hline Philopotamus sp. & & & 1 & & \\
\hline Polycentropus sp. & 1 & & & & \\
\hline Total number of taxa at locality & 12 & 2 & 9 & 5 & 3 \\
\hline
\end{tabular}




\section{Analysis of physico-chemical properties of water}

Within the research of the Despotovica River, basic physical and chemical parameters of water were followed and analysed, since they have an important influence on the composition and structure of communities in all aquatic ecosystems. The values of measured physical and chemical parameters are shown in Table 3.

Table 3. The physical and chemical parameters of water in research localities of the Despotovica River in April 2017.

\begin{tabular}{|c|c|c|c|c|c|}
\hline Parameter $\quad$ Localities & $\mathbf{L} \mathbf{1}$ & $\mathbf{L 2}$ & $\mathbf{L 3}$ & L4 & L5 \\
\hline Temperature $\left({ }^{\circ} \mathrm{C}\right)$ & 9 & 11.3 & 10.6 & 10.9 & 10.6 \\
\hline Conductivity $\left(\mu \mathrm{S} / \mathrm{cm}^{3}\right)$ & 564 & 671 & 435 & 431 & 518 \\
\hline Water hardness (mg/l) & 281 & 336 & 216 & 216 & 258 \\
\hline pH (0-14) & 7.97 & 7.67 & 8.09 & 7.03 & 8.06 \\
\hline Dissolved oxygen (mg/l) & 10.49 & 10.11 & 10.2 & 8.54 & 10.39 \\
\hline Oxygen saturation $(\%)$ & 96.2 & 97.9 & 104 & 79.7 & 96.6 \\
\hline Ammonium-ion ( $\left.\mathrm{NH}_{4}-\mathrm{N}\right)(\mathrm{mg} / \mathrm{l})$ & 3.2 & 0.44 & 0.02 & 0.29 & 0.19 \\
\hline Nitrate $\left(\mathrm{NO}_{3}-\mathrm{N}\right)(\mathrm{mg} / \mathrm{l})$ & 0.03 & 7 & 0.03 & 0.03 & 5 \\
\hline Ortofosfati (PO4-P) (mg/l) & 0.05 & 0.05 & 0.05 & 0.2 & 0.83 \\
\hline Total phosphorus (P) (mg/l) & 0.01 & 0.01 & 0.01 & 0.06 & 0.27 \\
\hline
\end{tabular}

\section{Ecological status assessment}

According to the Serbian National Regulation (AnONYMOUS, 2011b) the Despotovica River belongs to the water bodies of the Type 3 - small and medium watercourses, altitude up to $500 \mathrm{~m}$, dominance of a large substrate.

Based on analysis of epilithic diatom community parameters, prescribed by the Serbian National Regulation (ANONYMOUS, 2011b), indicative ecological status of the Despotovica River could be assessed as poor (IV class) (Table 4).

Table 4. Ecological status assessment (ESA) of the Despotovica River based on epilithic diatom community in April 2017.

\begin{tabular}{l|ccccc|c}
\hline \multicolumn{1}{c}{ Localities } & L1 & L2 & L3 & L4 & L5 & ESA \\
Parameter & & & & & & \\
\hline IPS indeks & 13.4 & 18.1 & 11.3 & 9.3 & 10 & poor \\
CEE indeks & $/$ & $/$ & 10.1 & 9.1 & 9 & moderate \\
\hline ESA & moderate & high & poor & poor & poor & poor \\
\hline
\end{tabular}

\section{*Legend}

high - I class $\quad$ good - II class $\quad$ moderate - III class $\quad$ poor - IV class

Down the Despotovica River, indicative ecological status assessment, based on parameters of epilithic diatom community, ranged from excellent (I class - L2) to poor (IV class - L3, L4 and L5). Values of the CEE index were not calculated at L1 and L2, while the value of the IPS index at L1 corresponded to the moderate ecological status (III class) (Table 4). 
The results of many authors confirmed that the ecological status assessment based on the IPS index is more trustworthy (VIDAKOVIĆ, 2013; VASILJEVIĆ et al., 2014, 2016, 2017; JAKOVLJEVIĆ et al., 2016b; PREDOJEVIĆ, 2017; VASILJEVIĆ, 2017), primarily because the IPS index usually integrates most of diatom species identified in the sample, as opposed to the CEE index. It was also noted that there was no difference in the boundary values between classes for the CEE index and Vasiljević suggests moving the boundary values for classes for types of watercourses (VASILJEVIĆ, 2017). According to Serbian National Regulation (ANONYMOUS, 2011b) only IPS index is used for assessment of the ecological potential for artificial and significantly modified water bodies (ČAĐO et al., 2016, 2017; DENIĆ et al., 2014a, 2014b, 2015b, 2015c).

Our research confirmed that the credibility of diatom indices depends on the number of taxa used for calculation (LECOINTE et al., 1993). As a consequence of using a small number of taxa, there were differences in estimation of the ecological status classes at the localities down the Despotovica River, based on aforementioned indices. In our research, values of the IPS index pointed to worse class than the values of the CEE index. At L1 and L2 sampling sites, the CEE index was not calculated due to small number of recorded taxa (Table 4).

At the L2, of a total of 4 recorded taxa (Achnanthidium microcephalum, Amphora veneta, Gomphonema olivaceum and Nitzschia palea), A. microcephalum (85.57\%) was the most frequent (Table 1). At this locality, the presence of teratological forms of $A$. microcephalum and $N$. palea was recorded. A. microcephalum is a cosmopolite that has a wide ecological valence and occurs in all types of water, from oligotrophic to eutrophic (KRAMMER AND LANGE-BERTALOT, 1991). The presence of teratological forms of diatoms may indicate an increase in heavy metals in water (VASILJEVIĆ, 2017; OLENICI et al., 2017). Sampling site L2 is located near the tailings pond of floatation of lead, copper and zinc ore. Teratological forms of A. microcephalum and associates are also found in waters loaded with lead and copper (OLENICI et al., 2017). Potential presence of heavy metals in the Despotovica River submitted (ANONYMOUS, 2011b) diatom indices are not able to detect, since they are designed to assess primarily organic pollution and nutrient loads.

High level of organic pollution on each locality, except L2, was also confirmed by recorded macroalgae. Based on saprobic list of indicators according to Sládeček (SLÁDEČEK, 1973), recorded species on these localities are indicators of exactly the same saprobic degree which could correspond to the classes of ecological status assessment. Cladophora glomerata, recorded at L1, on which the indicative ecological status is estimated as moderate (III class), is an indicator of $\beta$-mesosaprobic water quality. Stigeoclonium tenue and Ulothrix zonata are indicators of $\alpha$-mesosaprobic water quality, which corresponds to poor (IV class) ecological status assessment obtained by diatom indices at L3, L4 and L5. Macroalgae as a biological quality element are not included by the Serbian National Regulation (ANONYMOUS, 2011b).

Based on analysis of aquatic macroinvertebrate communities, indicative ecological status of the Despotovica River could be assessed as bad (V class) (Table 5).

Several authors have discussed relations between the community structure and water status (WASHINGTON, 1984; Rosenberg and Resh, 1993; ChAPMAn, 1996; Simić, 1996). In order to achieve an effective ecological status assessment, with high confidence, several metrics should be used.

Indicative ecological status, based on the parameters of aquatic macroinvertebrate community was assessed as bad at all localities, except at L1, where it was assessed as poor (Table 5).

A small number of identified species with the dominance of one or several species indicates stress in aquatic ecosystem. The mass development of Oligochaeta (Limnodrilus sp.) at L4, followed by the numerical reduction of the other macroinvertebrate representatives, indicates the presence of excessive organic matter and bad ecological status (Table 5). 
Table 5. Ecological status assessment (ESA) of the Despotovica River based on aquatic macroinvertebrate community in April 2017.

\begin{tabular}{l|cccccc}
\hline \multicolumn{1}{c}{ Localities } & L1 & L2 & L3 & L4 & L5 & ESA \\
Parameters & & & & & & \\
\hline Zelinka and Marvan SI & 2.24 & 2.1 & 2.17 & 3.41 & 2.96 & bad \\
BMWP score & 58 & 20 & 44 & 18 & 8 & bad \\
ASPT score & 6.4 & 10 & 5.5 & 3.6 & 2.6 & bad \\
Shannon-Weaver & 2.03 & 0.69 & 1.4 & 0.66 & 0.63 & poor \\
Total number of taxa & 12 & 2 & 9 & 5 & 3 & bad \\
Oligochaeta/Tubificidae & 0 & 0 & 0 & 76.68 & 6.81 & bad \\
EPT Index & 9 & 2 & 4 & 1 & 0 & bad \\
Total number of families & 10 & 2 & 9 & 5 & 3 & bad \\
BNBI Index & 3 & $/$ & 2.75 & 1.75 & 1.75 & bad \\
\hline ESA & poor & bad & bad & bad & bad & bad \\
\hline
\end{tabular}

*Legend

high - I class $\quad$ good - II class moderate - III class poor - IV class

Values of the Zelinka and Marvan Saprobic Index ranged from 2.1 ( $\beta$-mesosaprobity; L2 and L3) to 2.24 ( $\alpha$ - $\beta$-mesosaprobity; L1) and 3.41 (polysaprobity; L4) which indicate presence of organic pollution. These values correspond to Class V (bad status).

The lowest diversity was observed in the Despotovica river (Shannon-Weaver Diversity Index values ranging from 2.03 to 0.63 indicate an overall poor water quality (Class IV). Number of Ephemeroptera, Plecoptera and Trichoptera (EPT) taxa ranged from 9 (locality L1) to 0 (L5). Average values of EPT taxa correspond to Class V (bad status).

Calculated values of BMWP Score were in the range from 90 (L1) to as little as 8 (L5). Such BMWP Score values indicate bad status of the river (Class V). The highest ASPT value was 10 (L2) and the lowest was 2.6 (L5) (bad status).

Next to these parameters, and in accordance with the national legislation (Official Gazette of the Republic of Serbia 74/2011), the Balkan Biotic Index (BNBI) was also used (SIMIĆ and SIMIĆ, 1999), representing a combination of diversity index and characteristic dominant families, genera and characteristic species of macroinvertebrates only.

The values of BNBI index recorded in the localities L1 and L3 correspond with the Class IV (poor status). The remaining localities also had records of low values of the Class V index (bad status), which indicates a heavy load of organic matter in the water.

The SI values recorded at the Despotovica River show that p-mesosaprobic and $\alpha$ mesosaprobic bioindicators prevail, indicating a high presence of organic pollution and pointing to bad ecological status (Class V).

After taking into consideration all the parameters mentioned above, the indicative status of the Despotovica River could be assessed as bad (Class V), which corresponds to the water quality assessment based on the evaluation provided by national water quality monitoring for the period 2009-2010 (DENIĆ et al., 2015b), which generally assessed the Despotovica River as belonging to Class IV-V.

The assessment of the ecological status based on physico-chemical parameters of water is shown in Table 6.

Increased concentration of nutrients at localities influenced the ecological status of the Despotovica River based on physico-chemical parameters to be assessed as bad (V class) (Table 6). As physical and chemical parameters were measured one time, they can only preliminary indicate the abiotic conditions in this river. 
Table 6. Ecological status assessment (ESA) of the Despotovica River based on physico-chemical parameters in April 2017.

\begin{tabular}{|c|c|c|c|c|c|c|}
\hline $\begin{array}{ll}\text { Parameters } & \text { Localities } \\
\end{array}$ & L1 & $\mathbf{L 2}$ & $\mathbf{L 3}$ & L4 & L5 & ESA \\
\hline Dissolved oxygen (mg/l) & 10.49 & 10.11 & 10.2 & 8.54 & 10.39 & high \\
\hline Ammonium-ion $\left(\mathrm{NH}_{4}-\mathrm{N}\right)(\mathrm{mg} / \mathrm{l})$ & 3.2 & 0.44 & 0.02 & 0.29 & 0.19 & bad \\
\hline Nitrate $\left(\mathrm{NO}_{3}-\mathrm{N}\right)(\mathrm{mg} / \mathrm{l})$ & 0.03 & 7 & 0.03 & 0.03 & 5 & poor \\
\hline Orthophosphate $\left(\mathrm{PO}_{4}-\mathrm{P}\right)(\mathrm{mg} / \mathrm{l})$ & 0.05 & 0.05 & 0.05 & 0.2 & 0.83 & bad \\
\hline Total phosphorus (P) (mg/l) & 0.01 & 0.01 & 0.01 & 0.06 & 0.27 & moderate \\
\hline ESA & bad & poor & good & poor & bad & bad \\
\hline
\end{tabular}

*Legend

high - I class good - II class

moderate - III class

poor - IV class

Overall ecological status estimation of the Despotovica River in April 2017, based on parameters of biological (epilithic diatoms and aquatic macroinvertebrates) and supporting physico-chemical water quality elements, could be assessed as bad (V class) (Figure 2). Since all relevant parameters of recommended quality elements have been used in assessment, except specific pollutants, and that the frequency of monitoring is lower than the minimum predicted, the level of reliability of the ecological status assessment is medium (WFD, 2000).

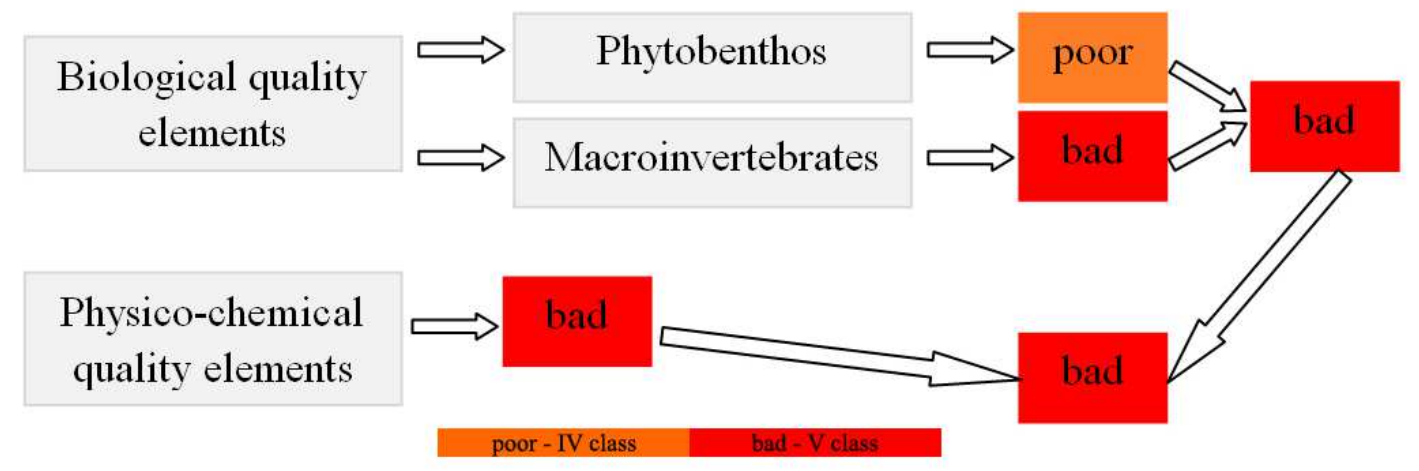

Figure 2. Overall ecological status assessment of the Despotovica River in April 2017.

Ecological status assessment of the Despotovica River, estimated on the base of aquatic macroinvertebrate community and physico-chemical parameters of water, in October 2015 was in the boundary between III-IV classes (SIMIĆ et al., 2015). Our results indicate the further degradation of this aquatic ecosystem.

\section{CONCLUSION}

Indicative ecological status of the Despotovica River in April 2017, based on condition of epilithic diatoms and macroinvertebrate communities, as well as physicochemical parameters of water, was assessed as bad (V class). The bad ecological status at L3, L4 and L5, based on the parameters of epilithic diatoms and aquatic macroinvertebrate communities, confirms the fact that these localities are under the influence of strong organic pollution. 
Our research confirms the fact that diatom indices IPS and CEE are good indicators of organic and inorganic pollution. At L2, ecological status based on IPS index was assessed as high, but the presence of teratological forms of diatoms indicates an increased presence of heavy metals at this locality.

The results of our research once again confirm that the IPS diatom index provides a more reliable assessment than CEE diatom index.

For a more precise picture of the ecological status of the Despotovica River, it has been recommended to carry out the monitoring at least four times a year and at more localities down the river. Also, all predicted parameters of biological (phytobenthos, macroinvertebrates, macrophytes and fish) and physico-chemical quality elements should be used for the final assessment of the ecological status.

\section{Acknowledgments}

This study was supported by the Ministry of Education and Science of the Republic of Serbia (Projects No. III 43002 and TP 31011).

\section{References:}

[1] AnONYMOUS (2010a): Zakon o vodama (Sl. glasnik RS 30/2010). [in Serbian]

[2] ANONYMOUS (2010b): Pravilnik o utvrđivanju vodnih tela površinskih i podzemnih voda (Sl. glasnik RS 96/2010). [in Serbian]

[3] ANONYMOUS (2011a): Pravilnik o referentnim uslovima za tipove površinskih voda (Sl. glasnik RS 67/2011). [in Serbian]

[4] AnONymous (2011b): Pravilnik o parametrima ekološkog i hemijskog statusa površinskih voda i parametrima hemijskog i kvantitativnog statusa podzemnih voda (Sl. glasnik RS 74/2011). [in Serbian]

[5] ANONYMOUS (2012): Pravilnik o graničnim vrednostima emisija zagađujućih materija u površinskim i podzemnim vodama i rokovi za njihovo postizanje (Sl. glasnik RS 50/2012). [in Serbian]

[6] Armitage, P.D., Moss, D., Wright, J.F. Furse, M.T. (1983): The performance of a new biological water quality score system based on macroinvertebrates over a wide range of unpolluted running-water sites. Water Research. 17, 333-347. doi: 10.1016/0043-1354(83)90188-4

[7] AQEM CONSORTIUM (2002): Manual for the application of the AQEM system. A comprehensive method to assess European streams using benthic macroinvertebrates developed for the purpose of the Water Framework Directive. Version 1.0 (www.aqem.de), February 2002, 202 pp.

[8] Belfiore, C. (1983): Guide per il riconoscimento delle specie animali delle acque interne italiane. Ephemerotteri (Ephemeroptera). Consiglio nazionale delle ricerche 24: $1-113$. 
[9] CemagreF (1982): Etude des méthodes biologiques quantitative d'appréciation quantitative de la qualité des eaux. Rapport Division Qualité des Eaux Lyon Agence financière de Bassin Rhône-Méditerranée-Corse, Pierre-Bénite, 218 pp.

[10] Chester, R. K. (1980): Biological Monitoring Working Party. The 1978 National Testing Exercise. Department of the Environment. Water Data Unit Technical Memorandum 18: 36.

[11] ČAĐO, S., Đurković, A., Denić, LJ., DopuĐa Glišić, T., Novaković, B., Veljović, N., Stojanović, Z. (2016): Ecological potential assessment of the Gruža reservoir. Water 2016: 45th Annual Conference of the Serbian Water Pollution Control Society, Conference Proceedings Zlatibor: 243-250. [in Serbian with English summary]

[12] ČAĐOO, S., Đurković, A., Denić, LJ., DopuĐa Glišić, T., NovaKović, B., Veljović, N., STOJANOvić, Z. (2017): Ecological potential assessment of the Ćelije reservoir. "Water 2017” Conference Proceedings, Vršac. [in Serbian with English summary]

[13] Denić, LJ., ČAĐO, S., Đurković, A., DopuĐa Glišić, T., Novaković, B., Stojanović, Z. (2014a): Ecological potential assessment of the Grlište reservoir based on biological and physco-chemical quality elements. Water 2014: 43rd Annual Conference of the Serbian Water Pollution Control Society, Conference Proceedings Tara: 57-64. [in Serbian with English summary]

[14] Denić, LJ., Đurković, A., ČAĐO, S., DopuĐa Glišić, T., Novaković, B., Stojanović, Z. (2014b): Ecological potential assessment of the Vrutci reservoir based on biological and physco-chemical quality elements. Water 2014: 43rd Annual Conference of the Serbian Water Pollution Control Society, Conference Proceedings Tara: 41-47. [in Serbian with English summary]

[15] Denić, LJ., ČAĐO, S., Đurković, A., Novaković, B., DopuĐA-Glišić, T., Veljković, N., Stojanović, Z., Milovanovic, J., Domanović, M. (2015a): Status površinskih voda Srbije. Analize i elementi za projektovanje monitoringa. Ministarstvo poljoprivrede i zaštite životne sredine, Agencija za zaštitu životne sredine, Beograd. [in Serbian]

[16] Denić, LJ., ČAĐO, S., Đurković, A., DopuĐa Glišić, T., Novaković, B., Stojanović, Z. (2015b): Ecological potential assessment of the Sjenica reservoir based on biological and physco-chemical quality elements. Water 2015: 44rd Annual Conference of the Serbian Water Pollution Control Society, Conference Proceedings Kopaonik: 59-64. [in Serbian with English summary]

[17] Denić, LJ., Đurković, A., ČAĐO, S., DopuĐa Glišić, T., StOJAnović, Z., Novaković, B. (2015c): Ecological potential assessment of the Prvonek reservoir based on biological and physco-chemical quality elements. Water 2015: 44rd Annual Conference of the Serbian Water Pollution Control Society, Conference Proceedings Kopaonik: 71-77. [in Serbian with English summary]

[18] DesCy, J.P., Coste, M. (1991): A test methods for assessing water quality based on diatoms. Verhandlung Internationale Vereingung de Limnologie 24: 2112-2116.

[19] Drinjaković, Z., Obradović, N., Tomić, Z., LaZović, S., SRbović, Z., Vasiluević, M., ĐOKOVIĆ, Đ., MARIĆ, R., GLIŠOviĆ, D. (2015): Lokalni ekološki akcioni plan opštine Gornji Milanovac - LEAP za period 2015. do 2025. godine. [in Serbian] 
[20] EN 13946 (2015): Water quality - Guidance standard for the routine sampling and pretreatment of benthic diatoms from rivers. Institute for Standardization of Serbia.

[21] EN 14407 (2015): Water quality - Guidance standard for the identification and enumeration of benthic diatom samples from rivers and lakes. Institute for Standardization of Serbia.

[22] EN ISO 5667 (part 1-19) (2017): Water quality - Sampling. Institute for Standardization of Serbia.

[23] Gavrilović, LJ., Dukić, D. (2002): Reke Srbije. Zavod za udžbenike i nastavna sredstva, Beograd. [in Serbian]

[24] HrabinovÁ, S., BitušíK, P. (2003): Hydrobiologický determinačný atlas, konzumenty II. Pakomărovitē (Chironomidae). Výskumný ústav vodného hospodárstva v Bratislave: 20-124.

[25] Ilić, M., Kračun, M., Tomović, J., Atanacković, A., Zorić, K., Vasiljević, B., Tubić, B., Marković, B., Paunović, M. (2013): Quality assessment of Belgrade reservoirs based on macroinvertebrate communities. Water 2013: 42rd Annual Conference of the Serbian Water Pollution Control Society, Conference Proceedings Perućac: 155-160. [in Serbian with English summary]

[26] JaKovljević, O S., KRIZMAnić, J.Ž., CviJan, M.V. (2014): Water quality assessment of the DTD canal system by diatom indices. Matica Srpska Journal for Natural Sciences 127: 23-33. doi: 10.2298/ZMSPN1427023J

[27] Jakovljević, O.S., Popović, S.S., Vidaković, D.P., Stojanović, K.Z., Krizmanić, J.Ž. (2016a): The application of benthic diatoms in water quality assessment (Mlava River, Serbia). Acta Botanica Croatica 75 (2): 199-205. doi: 10.1515/botcro-2016-0032

[28] Jakovljević, O., Popović, S., Živić, I., Stojanović, K., Krizmanić, J. (2016b): Benthic diatoms of the Vrla River (Serbia) and their application in the water ecological status assessment. Oceanological and Hydrobiological Studies 45 (3): 304-315. doi: 10.1515/ohs-2016-0029

[29] KocioleK, J.P. (2012): Diatoms of the Southern California Bight. http://dbmuseblade.colorado.edu/DiatomTwo/dscb_site/index.php Accessed on August, 2017.

[30] KomÁReK, J., Anagnostidis, K. (2005): Cyanoprokaryota 2. Teil: Oscillatoriales - In: Büdel, B., Gärtner, G., Krienitz, L., Schagerl, M. (eds.) Süßwasserflora von Mitteleuropa, Spektrum Akademischer Verlag, 19/2: 1-759.

[31] Krammer, K., Lange-Bertalot, H. (1986): Bacillariophyceae 1, Teil: Naviculaceae. In: Ettl, H., Gerloff, J., Heynig, H., Mollenhauer, D. (eds.) Süßwasserflora von Mitteleuropa. Gustav Fischer Verlag, Jena 2/1: 876.

[32] Krammer, K., Lange-Bertalot, H. (1988): Bacillariophyceae. 2. Teil: Bacillariaceae, Epithemiaceae, Surirellaceae. In: EtTl, H., GerlofF, J., HeYnig, H., MollenhaUeR, D. (eds.) Süßwasserflora von Mitteleuropa. Gustav Fischer Verlag, Stuttgart and Jena 2/2: 596. 
[33] Krammer, K., LAnge-Bertalot, H. (1991): Bacillariophyceae. 4. Teil: Achnanthaceae. Kritische Ergänzungen zu Navicula (Lineolatae) und Gomphonema. In: ETTL, H., Gartner, G., Gerloff, J., Heynig, H., Mollenhauer, D. (eds.) Süßwasserflora von Mitteleuropa. Gustav Fischer Verlag, Stuttgart and New York 2/4: 437.

[34] Krizmanić, J., Subakov Simić, G., Predojević, D. (2013): Algae as water quality bioindicators of the River Djetinja. VI International Conference "Water and Fish", Conference Proceedings, Belgrade: 342-348.

[35] Krizmanić, J, Subakov Simić, G, Vidaković, D, Marjanović, P. (2015): Water quality assessment of Vrutci reservoir tributaries based on diatom indices. VII International Conference "Water and Fish", Conference Proceedings, Belgrade: 318322.

[36] Lecointe, C., Coste, M., Prygiel, J. (1993): Omnidia: software for taxonomy, calculation of diatom indices and inventories management. Hydrobiologia 269/270: 509-513.

[37] Macan, T.T. (1955): A key to nymphs of British species of the family Caenidae (Ephem.). Entomologist's gazette: 127-142.

[38] Mann, K.H., Watson, E.V. (1964): A key to the British freshwater leeches with notes of their ecology. Freshwater biological associations, scientific publication 14 (2): 4-29.

[39] Marković, V., Atanacković, A., Tubić, B., Vasiljević, B., Simić, V., Tomović, J., Nikolić, V., PAunOvić, M. (2011): Indicative status assessment of the Velika Morava River based on aquatic macroinvertebrates. Water research and management 1 (3): 4753.

[40] Moog, O. (ed.) (1995): Fauna Aquatica Austriaca - A Comprehensive Species Inventory of Austrian Aquatic Organisms with Ecological Notes. Federal Ministry for Agriculture and Forestry, Wasserwirtschaftskataster Vienna: loose-leaf binder.

[41] Novaković, B. (2012): Indicative Ecological Status Assessment of the Južna Morava River Based on Aquatic Macroinvertebrates. Water research and management 2 (4): 4550 .

[42] Novaković, B. (2013a): Indicative Ecological Status Assessment of the Zapadna Morava River Based on Aquatic Macroinvertebrates. Water research and management. 3 (2): 37-43.

[43] Novaković, B. (2013b): Indicative ecological status assessment of the Jerma River based on aquatic macroinvertebrate communities. Water 2013: 42rd Annual Conference of the Serbian Water Pollution Control Society, Conference Proceedings, Perućac: 7380. [in Serbian with English summary]

[44] Novaković, B. (2014): Indicative Ecological Status Assessment of the Pek River Based on Aquatic Macroinvertebrate Communities. International Conference Ecological Improvement of devastated locations for sustainable development: conference proceedings, Belgrade: 191-197.

[45] Olenici, A., Blanco, S., Bornego-Ramos, M., Momeu L., Baciu, C. (2017): Exploring the effects of acid mine drainage on diatom teratology using geometric morphometry. Ecotoxicology 26 (8): 1018-1030. doi: 10.1007/s10646-017-1830-3 
[46] Popović, N., Marković, V., Atanacković, A., Vasiljević, B., AnĐus, S., Ilić, M., KraČUn-Kolarević, M., PAunoviĆ, M. (2015a): Water quality assessment of the Jablanica River based on aquatic macroinvertebrate community. VII International Conference "Water and Fish", Conference Proceedings, Belgrade: 434-438.

[47] Popović, N., Marković, V., Tomović, J., Đuknić, J., Tubić, B., Marinković, N., ČANAK-ATlAGiĆ, J., PAUnOviĆ, M. (2015b): Water quality assessment of the Mlava River based on aquatic macroinvertebrates. VII International Conference "Water and Fish”, Conference Proceedings, Belgrade: 439-443.

[48] Predojević, D. (2017): Ecological status assessment of the Zasavica River based on algological parameters. PhD thesis. Faculty of Biology, Belgrade. [in Serbian]

[49] ROYKOŠNÝ R. (1980): Klíč vodnich lareu hmyzu. Vydala academia nakladatelstvi Československé akademie véd, Praha: 512 pp.

[50] Shannon, C. E. (1948): A mathematical theory of communication. The Bell System Technical Journal, 27, 379-423. doi: 10.1002/j.1538-7305.1948.tb01338.x

[51] Simić, V. (1996): Possibilities of ecological monitoring of river systems in Serbia based on macrozoobenthos coomunities. PhD thesis. Faculty of Biology, Belgrade. [in Serbian]

[52] Simić, V., Simić, S., Radojković, N., ĐorĐević, N., Petrović, A. (2015): Izveštaj o proceni ekološkog statusa reke Despotovice. Prirodno-matematički fakultet, Kragujevac. 27. [in Serbian]

[53] Simić V., Simić S. (1999): Use of the river macrozoobenthos of Serbia to formulate a biotic index. Hydrobiologia 416: 51-64. Netherlands. doi: 10.1023/A:1003864610386

[54] SLÁdeČEK, V. (1973): System of water quality from the biological point of view. E. Schweizebatsche Verlagstbuchhondlung 7: 218.

[55] Stojanović, K, Živić, M, Dulić, Z, Marković, Z, KrizManić, J, MilošEvić, DJ, Miljanović, B, Jovanović, J, VidAKOvić, D, ŽIVIĆ, I. (2017): Comparative study of the effects of a small-scale trout farm on the macrozoobenthos, potamoplankton and epilithic diatom communities. Environmental Monitoring and Assessment 189 (8):403. doi: 10.1007/s10661-017-6114-0

[56] Spaulding, S.A., Lubinski, D.J., Potapova, M. (2010): Diatoms of the United States. http://westerndiatoms.colorado.edu Accessed on August 2017.

[57] Vasiljević, B., Krizmanić, J., Ilić, M., Marković, V., Tomović, J., Zorić, K., PAUNOVIĆ, M. (2014): Water quality assessment based on diatom indices - small hilly streams case study. Water Research and Management 4 (2): 31-35.

[58] Vasiljević, B., Simić, S., Paunović, M., Marinković, N., Đikanović, V., KračunKolaREVIĆ, M., ANĐUS, S. (2016): Diatom based assessment of the ecological status of the Sava River - 2014 case study. Book of abstracts $1^{\text {st }}$ GLOBAQUA International Conference "Managing the Effects of Multiple Stressors on Aquatic Ecosystems Under Water Scarcity”, Freising (Germany): 98-99. 
[59] Vasiljević, B. (2017): Benthic diatoms (Bacillariophyta) in assessment of the ecological status of the Velika Morava and Sava rivers. PhD thesis. Faculty of Science, Kragujevac. [in Serbian]

[60] Vasiljević, B., Simić, S., Paunović, M., Zuliani, T., Krizmanić, J., Marković, V., TOMOVIĆ, J. (2017): Contribution to the improvement of diatom-based assessments of the ecological status of large rivers - The Sava River Case Study. Science of The Total Environment 605-606: 874-883. doi: 10.1016/j.scitotenv.2017.06.206

[61] VidAKOvić, D. (2013): Assessment of the ecological status assessment of Raška River based on epilithic diatoms. Unpublished master thesis. Faculty of Biology, Belgrade. [in Serbian]

[62] Wehr, J. D., Sheath, R. G. (2003): Freshwater Algae of North America Ecology and Classification. Academic Press, USA. 826 pp.

[63] WFD (2000): Water Framework Directive - Directive of European Parliament and of the Council 2000/60/EC - Establishing a Framework for Community Action in the Field of Water Policy.

[64] Zelinka, M., MARVAn, P. (1961). Zur Präzisierung der biologischen Klassifikation der Reinheit fließender Gewässer. Arch. Hydrobiol. 57: 389-407

[65] Zorić, K., Raković, M., Vasiljević, B., Atanacković, A., Ilić, M., TANasković, A., PAUNOVIĆ, M. (2016): Ecological status of three reservoirs in sub-urban area of Belgrade (Serbia) based on macroinvertebrate assemblages. $2^{\text {nd }}$ Central European Symposium for Aquatic Macroinvertebrate Research. Book of abstracts, Pécs, Hungary: $132 \mathrm{pp}$. 